\title{
Asupan zat gizi makro dan kenaikan berat badan selama hamil terhadap luaran kehamilan
}

\author{
Macronutrient intake and gestational weight gain in correlation with pregnancy outcome \\ Imelda Fitri' ${ }^{1}$, Rizki Natia Wiji ${ }^{2}$
}

${ }^{1}$ Departemen Kebidanan, Fakultas Kedokteran dan Ilmu Kesehatan Universitas Abdurrab

${ }^{2}$ Diploma IV Kebidanan STIKes Al-Insyirah Pekanbaru

\begin{abstract}
Background: Based on neonatal nursing installation data at Arifin Achmad Regional Hospital in Riau Province, newborns with low birth weight have always been the highest cases. Objective: This study aimed to examine the effect of macronutrient status (carbohydrate, protein, fat) and gestasional weight gain on pregnancy outcomes. Method: Design used in this study was case-control. The study sample was 74 respondents, the case group was 37 mothers with babies born with low birth weight and the control group was 37 mothers with babies born with normal birth weight. Macronutrient intake was collected with a food frequency questionnaire (FFQ). Data was analyzed by using Chi-Square test ( $<<0,05)$. Results: Intake of low carbohydrate has 3 times risk for low birth weight $(O R=3.46$; 95\%CI:1.25-9.47), intake of low fat has 5 times risk for low birth weight (OR=5.11; 95\%CI:1.88-13.93), and intake of low protein has a 12 times risk for low birth weight $(O R=12.21 ; 95 \% C I: 3.97-37.94)$. A gestasional weight gain are not following the IOM recommendations increased the risk of giving birth to a low weight baby (OR=3.96; 95\%CI:1.49-10.53). Conclusion: Pregnant women with low intake of carbohydrates, proteins, fats, and weight gain are not following the recommended increased the risk of giving birth to a low weight baby.
\end{abstract}

KEY WORDS: low birth; macronutrient; pregnancy maternal; pregnancy outcome

\begin{abstract}
ABSTRAK
Latar belakang: Data tiga tahun terakhir di RSUD Arifin Achmad Provinsi Riau menunjukkan bahwa kasus berat badan lahir rendah (BBLR) selalu menjadi kasus tertinggi. Tujuan: Penelitian ini bertujuan untuk mengetahui pengaruh status gizi makro (karbohidrat, protein, lemak) dan kenaikan berat badan ibu selama hamil terhadap luaran bayi baru lahir. Metode: Desain penelitian case control dengan sampel penelitian adalah ibu nifas yang memenuhi kriteria inklusi dan eksklusi berjumlah 74 responden yaitu kelompok kasus sejumlah 37 ibu nifas dengan bayi BBLR dan kelompok kontrol sebanyak 37 ibu nifas dengan bayi berat badan lahir normal. Asupan zat gizi makro diperoleh dengan food frequency questionnaire (FFQ). Analisis data menggunakan uji Chi-Square. Hasil: Ibu hamil dengan asupan karbohidrat, lemak, dan protein yang kurang memiliki tiga kali (OR=3,46;95\%CI:1,25-9,47), lima kali $(\mathrm{OR}=5,11 ; 95 \% \mathrm{CI}: 1,88-13,93)$, dan dua belas kali $(\mathrm{OR}=12,21 ; 95 \% \mathrm{CI}: 3,97-37,94)$ lebih besar kemungkinan melahirkan bayi BBLR daripada ibu hamil dengan asupan karbohidrat, lemak, dan protein baik. Kenaikan berat badan ibu hamil yang tidak sesuai rekomendasi berisiko 3,96 kali lebih besar untuk melahirkan bayi dengan BBLR dibandingkan ibu hamil dengan kenaikan berat badan sesuai rekomendasi (OR=3,96; 95\% CI: 1,489-10,534). Simpulan: Ibu hamil dengan asupan gizi karbohidrat, protein, dan lemak yang tergolong kurang dan kenaikan berat badan tidak sesuai standar yang direkomendasikan berisiko melahirkan bayi dengan BBLR.
\end{abstract}

KATA KUNCI: berat badan lahir rendah; zat makro; ibu hamil; luaran bayi 


\section{PENDAHULUAN}

Angka kematian bayi (AKB) di Indonesia mencapai 32 per 1000 kelahiran hidup. Penurunan AKB di tahun 2013 tidak terlalu signifikan dibandingkan tahun 2007, yaitu menjadi 23 per 1.000 kelahiran hidup (1). Sebesar $60-80 \%$ kematian neonatal disebabkan oleh berat badan lahir rendah (BBLR). Berdasarkan data riset kesehatan dasar (Riskesdas) tahun 2013, persentase balita (0-59 bulan) dengan BBLR sebesar 10,2\%. Persentase BBLR tertinggi di Provinsi Sulawesi Tengah (16,8\%) dan terendah di Sumatera Utara (7,2\%) yang diikuti Provinsi Riau (9\%) (2). Namun demikian, menurut data di Instalasi Perawatan Neonatal Rumah Sakit Umum Daerah (RSUD) Arifin Achmad, yang merupakan rumah sakit rujukan dari kabupaten yang ada di Provinsi Riau, BBLR selalu menjadi kasus tertinggi. Angka kejadian BBLR pada tiga tahun terakhir menunjukkan peningkatan yaitu tahun 2013 sebanyak 145 bayi, tahun 2014 sebanyak 147 bayi, dan tahun 2015 sebanyak 153 bayi (3).

Penyebab terjadinya BBLR adalah kurangnya asupan gizi selama dalam kandungan yang berdampak pada terhambatnya pertumbuhan janin (intrauterine growth reterdation atau IUGR). Masalah gizi merupakan penyebab tidak langsung kematian ibu dan anak yang dapat dicegah, bayi dengan BBLR berpeluang meninggal 10-20 kali lebih besar dari bayi yang lahir dengan berat badan cukup (4). Asupan gizi selama hamil adalah salah satu faktor yang mempengaruhi berat bayi lahir. Hasil studi menyatakan adanya hubungan signifikan antara konsumsi protein ibu pada bulan terakhir kehamilan dengan ukuran bayi pada saat lahir. Semakin buruk asupan gizi ibu, maka semakin kurang ukuran panjang badan dan berat lahir bayi (5).

Tercukupinya asupan makan ibu saat hamil dapat dilihat dari pertambahan berat badan ibu selama kehamilan (6). Rerata total pertambahan berat badan ibu hamil berkisar 11,5 - $16 \mathrm{~kg}$ berdasarkan rekomendasi Institute of Medicine (IOM), dengan rerata $12 \mathrm{~kg}$ supaya dapat meningkatkan kemungkinan untuk melahirkan bayi cukup bulan dengan berat lahir cukup serta menurunkan risiko terjadinya komplikasi pada ibu dan bayi (7). Hasil studi melaporkan bahwa ibu yang mempunyai pertambahan berat badan selama kehamilan kurang dari 9,1 kg berisiko melahirkan bayi dengan berat lahir kurang dari $3.000 \mathrm{~g}(8)$.
Sebagian besar penelitian sebelumnya merupakan penelitian cross-sectional yang membahas rerata kenaikan berat badan ibu yang belum dikategorikan sesuai rekomendasi berdasarkan indeks masa tubuh (IMT). Selain itu, asupan gizi makro pada ibu hamil belum merujuk pada standar angka kecukupan gizi (AKG) untuk ibu hamil. Kasus BBLR berkontribusi besar terhadap terjadinya kematian neonatal, sementara penyebab terjadinya BBLR adalah asupan gizi ibu yang tidak adekuat selama kehamilan. Dengan demikian, tujuan penelitian ini adalah mengetahui pengaruh asupan zat gizi makro (karbohidrat, protein, lemak) dan kenaikan berat badan ibu selama hamil terhadap luaran bayi baru lahir di RSUD Arifin Achmad Provinsi Riau. Luaran bayi baru lahir dibatasi pada berat badan lahir.

\section{BAHAN DAN METODE}

Penelitian ini merupakan studi analitik observasional dengan rancangan case control yang dilakukan di RSUD Arifin Achmad Provinsi Riau pada bulan Maret-Agustus 2018. Penelitian dilaksanakan setelah mendapat persetujuan dari Komisi Etik Fakultas Kedokteran Universitas Riau dengan nomor 076/ UN.19.5.1.1.8/UEPKK/2018. Subjek penelitian adalah semua nifas di RSUD Arifin Achmad Provinsi Riau yang memenuhi kriteria inklusi dan eksklusi. Kriteria inklusi kasus yaitu ibu yang melahirkan bayi dengan BBLR (< $2500 \mathrm{~g}$ ), bayi lahir hidup, usia kehamilan cukup bulan (aterm) dan prematur (preterm), tercatat di rekam medik, mampu berkomunikasi, dan bersedia menjadi responden. Sementara itu, kriteria inklusi kontrol yaitu ibu yang melahirkan bayi dengan berat badan lahir normal ( $>2500$ g), bayi lahir hidup, dan usia kehamilan aterm. Kriteria eksklusi kasus dan kontrol yaitu ibu dengan komplikasi penyakit penyerta kehamilan dan bayi dengan kelainan kongenital atau cacat fisik. Berdasarkan perhitungan besar sampel menggunakan rumus matched case control studies (9) dengan tingkat kesalahan 5\%, kekuatan penelitian $80 \%$, dan $\mathrm{OR}=2$ (clinical judgement), maka diperoleh sampel minimal sebanyak 37 untuk masingmasing kelompok sehingga total sampel untuk kedua kelompok sebanyak 74 sampel. Pengambilan sampel menggunakan teknik non-probability sampling dengan 
metode concecutive sampling. Pengumpulan data secara langsung dengan melakukan wawancara kepada ibu nifas yang telah bersalin di RSUD Arifin Achmad Provinsi Riau yang dilakukan oleh peneliti dan dibantu 3 orang enumerator dengan pendidikan akhir Diploma IV Kebidanan.

Variabel independen yaitu asupan zat gizi makro (karbohidrat, lemak, protein) dan kenaikan berat badan selama hamil sedangkan variabel dependen yaitu luaran kehamilan berupa berat lahir bayi. Asupan zat gizi makro (karbohidrat, protein, lemak) diperoleh dengan semiquantitative food frequency questionnaire (SQ-FFQ) untuk mengetahui pola konsumsi makanan subjek selama hamil. Kategori zat gizi makro karbohidrat adalah nasi, havermouth, jagung, kentang, krekers/biscuit, mie kering, mie basah, bihun, roti putih, singkong, talas, ubi. Kategori zat gizi makro lemak adalah babat/jeroan, daging ayam dengan kulit, susu full cream, keju, alpukat, minyak goreng, minyak ikan, santan, minyak sayur bumbu (mie instan), margarin/mentega. Kategori zat gizi makro protein adalah daging sapi, daging kambing, daging ayam, telur ayam negeri, telur bebek, ikan laut segar, tahu, tempe, kacang tanah, kacang kedelai, oncom, kacang panjang, kacang hijau, buncis. Pertimbangan dalam pemilihan jenis bahan makanan tersebut berdasarkan standar baku kuesioner SQ-FFQ serta bahan makanan yang sudah dikenal dan rutin dikonsumsi setiap hari. Perhitungan nilai gizi setiap bahan makanan yang dikonsumsi yaitu dengan mengalikan berat (gram) setiap bahan makanan dengan frekuensi konsumsi dan mengkonversi seluruh kategori makanan dalam hari. Tingkat konsumsi (\%) dihitung berdasarkan rerata nilai gizi dari hasil SQFFQ dibagi dengan AKG dikali 100\%. Berdasarkan AKG, asupan karbohidrat, protein, dan lemak pada ibu hamil masing-masing terdapat penambahan $40 \mathrm{~g}, 20 \mathrm{~g}$, dan $10 \mathrm{~g}$ (10). Asupan karbohidrat, protein, dan lemak dikategorikan menjadi baik ( $\mathrm{AKG} \geq 80 \%$ ) dan kurang $(\mathrm{AKG}<80 \%)(11)$.

Kenaikan berat badan ibu selama hamil ditentukan berdasarkan selisih antara berat badan sebelum bersalin dengan berat badan awal kehamilan. Data berat badan awal kehamilan diperoleh dari kunjungan K1 ibu saat pemeriksaan antenatal care sedangkan berat badan sebelum bersalin diperoleh dari pemeriksaan berat badan ibu sebelum bersalin yang pencatatannya dicantumkan di buku Kesehatan Ibu dan Anak (KIA) dan dilakukan konfirmasi ulang saat anamnesis dengan subjek. Berdasarkan standar baku Institute of Medicine (IOM), kenaikan berat badan ibu selama hamil dikategorikan menjadi dua, yaitu sesuai rekomendasi dan tidak sesuai rekomendasi berdasarkan IMT prahamil yang merupakan hasil pembagian berat badan prahamil dan kuadrat tinggi badan subjek. Data tinggi badan subjek diperoleh dari buku KIA dan ditanyakan kembali saat wawancara. Kenaikan berat badan berdasarkan IMT prahamil dikategorikan sesuai rekomendasi jika: 1) kenaikan berat badan 12,5-18 $\mathrm{kg}$ untuk status gizi kurang (IMT $<18,5$ $\left.\mathrm{kg} / \mathrm{m}^{2}\right)$; 2) kenaikan berat badan 11,5-16 kg untuk status gizi normal (IMT 18,5-24,9 kg/m²); 3) kenaikan berat badan 7-11,5 kg untuk status gizi lebih $\left(25,0-29,9 \mathrm{~kg} / \mathrm{m}^{2}\right)$; 4) kenaikan berat badan 5-9 $\mathrm{kg}$ untuk status gizi obesitas $\left(\geq 30 \mathrm{~kg} / \mathrm{m}^{2}\right)$ (7). Berat badan bayi lahir diperoleh dari hasil wawancara dengan subjek dan dipastikan dengan melihat data rekam medis.

Analisis bivariat untuk mengetahui pengaruh asupan zat gizi makro (karbohidrat, lemak, protein) dan kenaikan berat badan ibu selama hamil terhadap luaran bayi baru lahir dengan menggunakan uji Chi-Square yang bermakna bila $\mathrm{p}<0,05$.

\section{HASIL}

Karakteristik responden pada Tabel 1 menunjukkan bahwa sebagian besar subjek termasuk dalam kategori umur tidak berisiko (79,7\%); IMT normal (66,2\%); asupan karbohidrat baik (64,9\%); asupan protein baik $(56,8 \%)$; asupan lemak baik (56,8\%); dan kenaikan berat badan tidak sesuai rekomendasi (56,8\%). Subjek yang memiliki asupan karbohidrat, protein, dan lemak tergolong baik, sebagian besar berada pada kelompok berat lahir normal. Sebalikya, subjek dengan asupan karbohidrat, protein, dan lemak yang tergolong kurang lebih banyak ditemukan pada kelompok BBLR (69,2\%; 81,2\%; dan 71,9\%). Lebih lanjut, subjek dengan kenaikan berat badan selama hamil yang tidak sesuai rekomendasi lebih banyak ditemukan dengan luaran kehamilan BBLR $(64,3 \%)$.

Lebih lanjut Tabel 2 menunjukkan bahwa asupan zat gizi makro yaitu karbohidrat $(\mathrm{p}=0,028)$, protein 
Tabel 1. Karakteristik responden

\begin{tabular}{|c|c|c|c|c|c|c|}
\hline \multirow{3}{*}{ Variabel } & \multicolumn{4}{|c|}{ Kelompok } & \multirow{2}{*}{\multicolumn{2}{|c|}{ Total }} \\
\hline & \multicolumn{2}{|c|}{ Normal $(n=37)$} & \multicolumn{2}{|c|}{$\operatorname{BBLR}(n=37)$} & & \\
\hline & $\mathbf{n}$ & $\%$ & $\mathbf{n}$ & $\%$ & $\mathbf{n}$ & $\%$ \\
\hline \multicolumn{7}{|l|}{ Umur (tahun) } \\
\hline Tidak berisiko (20-35) & 26 & 44,1 & 33 & 55,9 & 59 & 79,7 \\
\hline Berisiko $(<20$ dan $>35)$ & 11 & 73,3 & 4 & 26,7 & 15 & 20,3 \\
\hline \multicolumn{7}{|l|}{ Indeks massa tubuh } \\
\hline Normal & 23 & 46,9 & 26 & 53,1 & 49 & 66,2 \\
\hline Tidak Normal & 14 & 56,0 & 11 & 44,0 & 25 & 33,8 \\
\hline \multicolumn{7}{|l|}{ Asupan karbohidrat } \\
\hline Baik & 29 & 60,4 & 19 & 39,6 & 48 & 64,9 \\
\hline Kurang & 8 & 30,8 & 18 & 69,2 & 26 & 35,1 \\
\hline \multicolumn{7}{|l|}{ Asupan protein } \\
\hline Baik & 31 & 73,8 & 11 & 26,2 & 42 & 56,8 \\
\hline Kurang & 6 & 18,8 & 26 & 81,2 & 32 & 43,2 \\
\hline \multicolumn{7}{|l|}{ Asupan lemak } \\
\hline Baik & 28 & 66,7 & 14 & 33,3 & 42 & 56,8 \\
\hline Kurang & 9 & 28,1 & 23 & 71,9 & 32 & 43,2 \\
\hline \multicolumn{7}{|l|}{$\begin{array}{l}\text { Kenaikan berat badan } \\
\text { selama hamil }\end{array}$} \\
\hline Sesuai rekomendasi & 22 & 68,8 & 10 & 31,2 & 32 & 43,2 \\
\hline Tidak sesuai rekomendasi & 15 & 35,7 & 27 & 64,3 & 42 & 56,8 \\
\hline
\end{tabular}

Tabel 2. Hasil analisis pengaruh asupan zat gizi makro dan kenaikan berat badan terhadap berat lahir

\begin{tabular}{|c|c|c|c|c|c|c|}
\hline \multirow{3}{*}{ Variabel } & \multicolumn{4}{|c|}{ Berat badan lahir } & \multirow{3}{*}{$\mathbf{p}$} & \multirow{3}{*}{$\begin{array}{c}\text { OR } \\
\text { CI } 95 \%\end{array}$} \\
\hline & \multicolumn{2}{|c|}{ Normal } & \multicolumn{2}{|c|}{ BBLR } & & \\
\hline & $\mathbf{n}$ & $\%$ & $\mathbf{n}$ & $\%$ & & \\
\hline Karbohidrat & & & & & 0,028 & 3,43 \\
\hline Baik & 29 & 60,4 & 19 & 39,6 & & $(1,25-9,47)$ \\
\hline Kurang & 8 & 30,8 & 18 & 69,2 & & \\
\hline Protein & & & & & 0,000 & 12,21 \\
\hline Baik & 31 & 73,8 & 11 & 26,2 & & $(3,97-37,54)$ \\
\hline Kurang & 6 & 18,8 & 26 & 81,2 & & \\
\hline Lemak & & & & & 0,002 & 5,11 \\
\hline Baik & 28 & 66,7 & 14 & 33,3 & & $(1,88-13,93)$ \\
\hline Kurang & 9 & 28,1 & 23 & 71,9 & & \\
\hline Kenaikan berat badan selama hamil & & & & & 0,010 & 3,960 \\
\hline Sesuai rekomendasi & 22 & 68,8 & 10 & 31,2 & & $(1,489-10,534)$ \\
\hline Tidak sesuai rekomendasi & 15 & 35,7 & 27 & 64,3 & & \\
\hline
\end{tabular}

$(\mathrm{p}=0,000)$, dan lemak $(\mathrm{p}=0,002)$ berpengaruh signifikan terhadap berat lahir bayi $(\mathrm{p}<0,05)$. Demikian juga dengan kenaikan berat badan selama hamil yang berpengaruh signifikan terhadap berat lahir bayi $(p=0,010)$. Ibu hamil yang melahirkan bayi dengan BBLR lebih banyak terjadi pada ibu dengan asupan karbohidrat kurang dibandingkan ibu dengan asupan karbohidrat baik $(\mathrm{OR}=3,43 ; 95 \%$ CI: 1,25 - 9,47). Artinya, ibu hamil dengan asupan karbohidrat kurang berisiko 3,43 kali lebih besar untuk melahirkan bayi dengan BBLR dibandingkan ibu dengan asupan karbohidrat baik. Demikian juga untuk ibu hamil dengan asupan protein dan lemak yang tergolong kurang berisiko 12,21 kali $(\mathrm{OR}=12,21$; 95\% CI: 3,9737,54) dan 5,11 kali (OR=5,11; 95\% CI: 1,88 - 13,93) lebih besar untuk melahirkan bayi dengan BBLR dibandingkan ibu dengan asupan protein dan lemak baik. 
Di samping itu, kenaikan berat badan ibu hamil yang tidak sesuai rekomendasi berisiko 3,96 kali lebih besar untuk melahirkan bayi dengan BBLR dibandingkan ibu hamil dengan kenaikan berat badan sesuai rekomendasi (OR=3,96; 95\% CI: 1,489-10,534).

\section{BAHASAN}

\section{Pengaruh asupan zat gizi makro karbohidrat ibu hamil terhadap berat lahir}

Hasil analisis menunjukkan bahwa ibu dengan asupan karbohidrat kurang memiliki tiga kali lebih besar kemungkinan melahirkan bayi BBLR daripada ibu dengan asupan karbohidrat baik. Hasil studi longitudinal menemukan adanya peningkatan laju metabolisme basal (basal metabolic rate/BMR) dari prahamil sebesar 5\%, $11 \%$, dan $24 \%$ masing-masing pada trimester pertama, kedua, dan ketiga. Peningkatan BMR untuk wanita dengan IMT rendah dan normal nilainya hampir sama, tetapi peningkatan BMR lebih besar untuk wanita dengan IMT yang tinggi (7\%, 16\%, dan 38\% untuk setiap trimester) (12). Kebutuhan energi untuk menunjang peningkatan metabolisme tersebut sekitar $85.000 \mathrm{kkal}$ untuk 40 minggu masa kehamilan sehingga tambahan rerata kebutuhannya sekitar $300 \mathrm{kkal} /$ hari. Kebutuhan kalori wanita hamil trimester III meningkat hingga 40\%, jika kebutuhan karbohidrat tidak tercukupi, maka akan mempengaruhi berat lahir bayi. Karbohidrat berperan penting dalam pembesaran sel pada proses hipertrofi yang akan mempengaruhi pertambahan berat badan bayi, terutama pada trimester tiga kehamilan (13). Karbohidrat dikenal sebagai zat gizi makro sumber bahan bakar (energi) utama bagi tubuh (14).

Prevalensi BBLR lebih tinggi pada wanita hamil dengan asupan energi kurang dari 70\% AKG (15). Hasil review menyimpulkan asupan makanan selama kehamilan adalah penentu utama berat lahir, selain juga dipengaruhi oleh banyak faktor biologis, sosial, dan demografis. Tidak hanya asupan gizi makronutrien tetapi mikronutrien juga berperan penting dalam pertumbuhan dan perkembangan janin (16). Sejalan dengan studi sebelumnya bahwa asupan zat gizi makronutrein (energi, karbohidrat, protein, lemak) yang kurang, lebih berisiko untuk melahirkan bayi dengan BBLR (17).
Karbohidrat dapat memenuhi hampir $60 \%$ kalori yang dibutuhkan oleh ibu hamil. Jika kebutuhan energi yang dihasilkan oleh karbohidrat tersebut mencukupi, maka akan membantu dalam pembentukan plasenta, pertumbuhan janin, pembuluh darah, cadangan lemak, serta perubahan metabolisme. Sebaliknya, ibu dengan status gizi kurang akan mengalami gangguan pertumbuhan dan fungsi plasenta yang berdampak pada berat dan ukuran plasenta yang lebih kecil. Malnutrisi pada ibu akan mengurangi aliran darah ke plasenta dan mengurangi transfer zat gizi ke janin sehingga ukuran plasenta abnormal yang menyebabkan BBLR (18).

\section{Pengaruh asupan zat gizi makro lemak ibu hamil terhadap berat lahir}

Penelitian ini menunjukkan bahwa ibu dengan asupan lemak kurang memiliki lima kali lebih besar kemungkinan melahirkan bayi BBLR daripada ibu dengan asupan lemak baik. Hasil ini didukung oleh studi intervensi pada wanita berpenghasilan rendah di Chili yang menemukan peningkatan berat badan lahir $(118 \mathrm{~g})$, panjang badan $(0,57 \mathrm{~cm})$, dan lingkar kepala $(0,20 \mathrm{~cm})$ pada ibu hamil yang menerima mikronutrien dosis tinggi bersama dengan asam lemak omega-3 (19). Studi literatur review juga menyimpulkan bahwa asupan asam lemak omega-3, khususnya asam dokosaheksaenoat (DHA), selama kehamilan, menyusui, dan kehidupan awal, memiliki manfaat yang signifikan untuk pertumbuhan dan perkembangan bayi terutama di negara berkembang. Asam lemak tak jenuh ganda rantai panjang terutama DHA, adalah agen neurobiologis yang kuat yang mempengaruhi struktur membran neuronal, sinaptogenesis, dan mielinisasi $(20,21)$.

Hasil literatur review tersebut juga menunjukkan adanya hubungan positif antara status asam lemak omega-6 dan omega-3 ibu dengan berat lahir, panjang lahir, dan komposisi tubuh anak saat masih bayi. Status omega-6 dan omega-3 yang tinggi menimbulkan jaringan asam arakidonat (AA) yang meningkatkan produksi prostasiklin dan pada akhirnya merangsang jalur persinyalan yang terlibat dalam adipogenesis. Selain itu, disebutkan juga pentingnya menyediakan pasokan asam lemak omega-3 dan omega-6 yang tepat, terutama DHA dan AA, karena kedua asam lemak ini terus terakumulasi 
paling cepat dalam materi abu-abu otak selama dua tahun pertama kehidupan. Selama trimester ketiga kehamilan dan tahun pertama kehidupan, otak tumbuh dengan cepat dan asupan yang cukup dari kedua asam lemak ini dianggap penting untuk perkembangan optimal (21). Otak manusia mengalami perubahan struktural dan fungsional yang luar biasa antara 24 sampai 44 minggu setelah konsepsi yaitu berkembang pada awal trimester ketiga (20).

Menurut WNPG, asupan lemak yang tergolong baik adalah $20-30 \%$ dari total energi. Namun, pada ibu dengan IMT lebih tinggi, harus memperhatikan asupan lemak karena ibu pada kategori ini cenderung mendapatkan energi dari lemak dan rentan untuk memiliki kenaikan berat badan yang berlebih (22). Lemak dipecah di dalam usus oleh enzim lipase yang dibantu oleh hormone kolesistokinin. Semua makanan yang telah dicerna di usus kemudian dapat diabsorbsi melalui sel-sel mukosa pada dinding usus dan disimpan pada jaringan adiposa dan jaringan bawah kulit. Jika diperlukan maka lemak akan diangkut menuju hati untuk disebarkan ke seluruh tubuh, terutama pada kondisi ibu hamil dengan peningkatan metabolisme tubuh untuk memenuhi kebutuhan ibu dan janin. Bayi dengan BBLR kemungkinan juga disebabkan oleh ketidakseimbangan hormonal atau penyerapan tubuh ibu yang kurang baik ketika hamil sehingga transfer lemak ke janin tidak sempurna dan kebutuhan bayi akan lemak tidak tercukupi (23).

\section{Pengaruh asupan zat gizi makro protein ibu hamil terhadap berat lahir}

Studi ini menunjukkan bahwa ibu hamil dengan asupan protein kurang akan berisiko 12 kali lebih besar untuk melahirkan bayi BBLR dibandingkan ibu dengan asupan protein baik. Studi lain menyebutkan bahwa asupan protein yang rendah dapat meningkatkan risiko terjadinya kekurangan energi kronis (KEK) pada wanita usia subur. Lebih lanjut, apabila wanita dengan KEK memiliki asupan protein yang kurang maka akan meningkatkan terjadinya BBLR dan gizi buruk pada bayi (24). Hasil ini didukung oleh studi sebelumnya yang menyatakan bahwa tingkat kecukupan energi $(\mathrm{r}=0,568)$ dan protein $(r=0,541)$ berhubungan dengan berat bayi lahir. Secara multivariat, tingkat kecukupan protein dan asupan Fe harian ibu hamil trimester III berhubungan dengan berat badan lahir bayi (25). Studi lain pada ibu hamil remaja juga menemukan bahwa asupan protein yang rendah berpeluang melahirkan bayi BBLR sebesar 13 kali lebih besar dibandingkan ibu hamil remaja dengan asupan protein cukup (26).

Kebutuhan protein pada ibu hamil meningkat terutama pada trimester II dan III. Hampir $70 \%$ protein dalam tubuh ibu hamil digunakan untuk membentuk jaringan baru dan pertumbuhan janin yang sangat cepat. Konsekuensi dari kekurangan protein pada ibu hamil secara signifikan berdampak pada panjang dan berat bayi lahir. Asupan protein yang rendah juga akan berpengaruh terhadap total asupan energi pada ibu hamil (27). Literatur review menyebutkan adanya perbedaan kualitatif dalam persyaratan diet selama awal dan akhir kehamilan yaitu mikronutrien dan protein diperlukan pada awal kehamilan, sementara kalori dan nutrisi lainnya pada usia kehamilan selanjutnya. Bukti dari sistematis review studi randomized controlled trials efektivitas intervensi gizi yang bertujuan mengurangi retardasi pertumbuhan intrauterin (IUGR) menyimpulkan efek menguntungkan dari makronutrien (protein dan energi) untuk mengurangi kejadian IUGR (23). Namun demikian, semua nutrisi berperan penting untuk pertumbuhan dan perkembangan sel saraf, tetapi beberapa tampaknya memiliki efek yang lebih besar selama periode akhir janin dan neonatal yaitu protein, besi, seng, selenium, yodium, folat, vitamin A, kolin, dan asam lemak tak jenuh ganda rantai panjang. Dengan demikian, kondisi malnutrisi energi protein pada janin akan menghasilkan retardasi pertumbuhan intrauterin yang disebabkan oleh malnutrisi berat selama kehamilan (20).

\section{Pengaruh kenaikan berat badan ibu selama hamil terhadap berat lahir}

Berdasarkan hasil analisis, diketahui bahwa ibu hamil yang kenaikan berat badannya tidak sesuai rekomendasi memiliki tiga kali lebih besar kemungkinan melahirkan bayi BBLR dibandingkan ibu yang kenaikan berat badannya sesuai rekomendasi. Sejalan dengan studi di China pada 1.617 pasang ibu dan anak yang menyimpulkan bahwa ibu dengan pertambahan berat badan kehamilan di bawah pedoman IOM, cenderung 
memiliki anak dengan berat lahir rendah $(\mathrm{OR}=2.2$; 95\% CI: 1.1-4.4) dibandingkan wanita yang memiliki pertambahan berat badan kehamilan sesuai pedoman IOM (28). Berat badan ibu sebelum hamil dan penambahan berat badan selama hamil merupakan penentu utama berat bayi saat lahir. Wanita dengan berat badan rendah $(<55 \mathrm{~kg}$ ) sebelum hamil yang mencapai sedikit kenaikan berat badan selama hamil mempunyai insidensi lebih tinggi untuk melahirkan bayi dengan BBLR dibandingkan wanita dengan berat badan awal kehamilan dan kenaikan berat badan selama hamil yang lebih besar (27). Hasil studi kohort observasional prospektif di Norwegia membuktikan bahwa kenaikan berat badan tidak sesuai standar IOM berpeluang melahirkan BBLR sebesar 2,16 kali untuk wanita nulipara dan sebesar 1,56 kali untuk wanita multipara. Sementara itu, wanita dengan berat badan prakehamilan normal dan overweight dengan kenaikan berat badan melebihi standar IOM berisiko hipertensi, makrosomia, preeklamsi, dan melahirkan caesar pada wanita primipara dan multipara (29).

Peningkatan berat badan ibu hamil dipengaruhi oleh banyak faktor, diantaranya tingkat edema, laju metabolik, asupan makan, jumlah cairan amnion, dan ukuran janin. Usia maternal, ukuran tubuh prakehamilan, paritas, hipertensi, dan diabetes juga mempengaruhi pola peningkatan berat badan ibu hamil (30). Penambahan berat badan pada kehamilan meliputi tiga komponen yaitu, 1) hasil konsepsi: janin, plasenta, cairan ketuban; 2) jaringan dalam tubuh ibu: uterus, buah dada, dan volume darah meningkat; 3) cadangan lemak ibu dengan rerata sebanyak $30 \%$ dari total penambahan berat badan (31). Hasil review menyebutkan bahwa kenaikan berat badan yang optimal selama kehamilan dan hasil janin yang diinginkan merupakan hasil dari efek sinergis peningkatan asupan makanan, suplementasi makanan, peningkatan asupan mikronutrien, pendidikan, dan lingkungan wanita hamil dan keluarganya (23).

Dengan demikian, pemantauan berat badan selama hamil sangat penting yang dapat dilakukan pada saat pemeriksaan kehamilan antenatal care (ANC). Semakin sering ibu hamil melakukan ANC pada tenaga kesehatan, maka kenaikan berat badan saat hamil akan mudah diawasi (32). Peningkatan berat badan selama kehamilan merupakan indikator untuk menilai kesehatan ibu dan janin. Pola penambahan berat badan yang berkelanjutan lebih penting daripada total penambahan berat badan (7). Konsumsi pangan baik kualitas maupun kuantitas sangat perlu diperhatikan karena mempengaruhi status gizi (33) terutama adanya peningkatan metabolisme dalam masa kehamilan yang pada akhirnya mempengaruhi berat lahir bayi. Penanggulangan masalah gizi dan kesehatan untuk meningkatkan kualitas sumber daya manusia, paling tepat dilakukan pada masa menjelang dan saat prenatal. Alasan yang mendukung yaitu perkembangan otak dimulai pada masa kehamilan dan ibu hamil yang menderita defisiensi zat gizi berisiko lebih besar untuk melahirkan bayi dengan BBLR. Selanjutnya, bayi BBLR berisiko lebih besar untuk meninggal pada usia satu tahun dan jika mampu bertahan hidup akan berisiko lebih besar untuk menderita penyakit degeneratif pada usia yang lebih muda dibandingkan dengan bayi dengan berat lahir normal. Bayi BBLR juga dapat menyebabkan kekerdilan (stunting) jika kondisi kesehatan dan makanan tidak mencukupi selama perkembangan setelah kelahiran. Dampak yang lebih luas yaitu menurunkan kecerdasan, mengganggu pertumbuhan, imunitas rendah, dan peningkatan morbiditas serta mortalitas dengan munculnya penyakit degeneratif saat dewasa. Memperhatikan dampak kurang gizi yang sangat luas, maka diperlukan upaya yang tepat bagi penangganan gizi ibu hamil $(34,35)$.

\section{SIMPULAN DAN SARAN}

Asupan zat gizi makro (karbohidrat, protein, lemak) dan kenaikan berat badan ibu hamil berpengaruh terhadap berat lahir. Ibu hamil dengan asupan zat gizi makro kurang dan kenaikan berat badan selama hamil tidak sesuai rekomendasi, berisiko lebih besar untuk melahirkan bayi BBLR. Ibu hamil perlu memperhatikan asupan gizi dan status gizi sejak awal kehamilan serta memberikan perhatian terhadap pertambahan berat badan selama kehamilan karena berpengaruh terhadap berat lahir bayi yang akan dilahirkan. Diharapkan terealisasinya program dari RSUD Arifin Achmad untuk perbaikan gizi ibu hamil dalam upaya menurunkan kasus BBLR.

\section{Pernyataan konflik kepentingan}

Tidak ada konflik kepentingan dalam penelitian ini. 


\section{RUJUKAN}

1. Badan Kependudukan dan Keluarga Berencana Nasional, Badan Pusat Statistik, Kementerian Kesehatan RI, dan ICF International. Survei Demografi Kesehatan Indonesia (SDKI). Jakarta: BKKBN, BPS, Kementerian Kesehatan, dan ICF International; 2013.

2. Badan Penelitian dan Pengembangan. Riset Kesehatan Dasar (Riskesdas) tahun 2013. Jakarta: Kesehatan Kementerian RI; 2013.

3. RSUD Arifin Achmad Provinsi Riau. Laporan tahunan RSUD Arifin Achmad Provinsi Riau. Riau: RSUD Arifin Achmad Provinsi Riau; 2017.

4. Chairunita. Model penduga berat bayi lahir berdasarkan pengukuran lingkar pinggang ibu hamil [Tesis]. Bogor: Pasca Sarjana Institut Pertanian Bogor; 2006.

5. Boer JMA, van Bakel AM, Hoogervorst E, Luijten M, de Vries A. (2009). Effects of maternal diet during pregnancy on birth weight of the infant. National Institute for Public Health and the Environment, Report 350020009/2009. [series online] 2009 [cited 5 Januari 2018]. Available online: URL: https://www.rivm.nl/ bibliotheek/rapporten/350020009.pdf

6. Aritonang, Evawany. Kebutuhan gizi ibu hamil, Bogor: IPB Press; 2010.

7. Institute of Medicine (IOM) and National Research Council (NRC) Committee to Reexamine IOM Pregnancy Weight Guidelines. Rasmussen KM, Yaktine AL, editor. Weight gain during pregnancy: reexamining the guidelines. [series online] 2009 [cited 5 Januari 2018]. Available online: https://www.ncbi.nlm.nih.gov/books/NBK32813/

8. Anies I, Triwinarto A, Salimar, Raswanti I. Pengaruh status gizi ibu selama kehamilan dan menyusui terhadap keberhasilan pemberian air susu ibu. Penelitian Gizi dan Makanan 2003;26(2):10-19.

9. Lemeshow S, Hosmer DW, Klar J, Lwanga SK. Besar sampel dalam penelitian kesehatan. Yogyakarta: Gadjah Mada University Press; 1997.

10. Widyakarya Nasional Pangan dan Gizi (WNPG). Pemantapan ketahanan pangan dan perbaikan gizi berbasis kemandirian dan kearifan lokal. Jakarta: Lembaga Ilmu Pengetahuan Indonesia (LIPI); 2012.

11. Sirajuddin D. Survei konsumsi pangan. Jakarta: EGC; 2014.

12. Ritchie LD, King JC. Nutrient recommendations and dietary guidelines for pregnant women. In: Lammi-Keefe CJ, Couch SC, Philipson EH (editor). Handbook of nutrition and pregnancy. Totowa, NJ: Humana Press; 2008.

13. Fikawati S. Gizi ibu dan bayi. Jakarta: Rajawali Pers; 2015.

14. Kurniasih D, Hilmansyah H, Astuti MP, Imam S. Sehat dan bugar berkat gizi seimbang. Jakarta: Gramedia; 2010.
15. Metgud CS, Naik VA, Mallapur MD. Factors affecting birth weight of a newborn - a community based study in Rural Karnataka, India. PLos One 2012;7(7):e40040. doi: 10.1371/journal.pone.0040040.

16. Tyagi S, Toteja DS, Bhatia N. Maternal nutritional status and its relation with birth weight. Int J Health Sci Res 2017;7(8):422-33.

17. Syari M, Serudji J, Mariati U. Peran asupan zat gizi makronutrien ibu hamil terhadap berat badan lahir bayi di Kota Padang. Jurnal Kesehatan Andalas 2015;4(3):729-36.

18. Worthington R, Williams S. Nutrition throughout the life cycle. USA: Mc Graw Hill; 2000.

19. Mardones F, Urrutia MT, Villarroel L, Rioseco A, Castillo O, Rojas I, et al. Effects of a dairy product fortified with multiple micronutrients and omega-3 fatty acids on birth weight and gestation duration in pregnant Chilean women. Public Health Nutr. 2008;11(1):30-40. doi: 10.1017/ S1368980007000110

20. Georgieff MK. Nutrition and the developing brain: nutrient priorities and measurement. Am J Clin Nutr 2007;85(2):614-20S.

21. Huffman SL, Harika RK, Eilander A, Osendarp SJM. Essential fats: how do they affect growth and development of infants and young children in developing countries? a literature review. Matern Child Nutr. 2011;7 Suppl 3:44-65. doi: 10.1111/j.1740-8709.2011.00356.x.

22. Supriasa D. Penilaian status gizi. Jakarta: EGC; 2013.

23. Muthayya S. Maternal nutrition \& low birth weight - what is really important? Indian J Med Res. 2009;130(5):6008.

24. Aprilianti D, Purba JSR. Hubungan pengetahuan, sikap, asupan energi dan protein terhadap risiko kurang energi kronik (KEK) pada wanita usia subur di Desa Hibun Kabupaten Sanggau. Pontianak Nutrition Journal 2018;1(1):36-9.

25. Rukmana SC, Kartasurya MI. Hubungan asupan gizi dan status gizi ibu hamil trimester III dengan berat badan lahir bayi di wilayah kerja Puskesmas Suruh Kabupaten Semarang. Journal of Nutrition College 2014;3(1):192-9.

26. Retni, Margawati A, Widjanarko B. Pengaruh status gizi \& asupan gizi ibu terhadap berat bayi ahir rendah pada kehamilan usia remaja. Jurnal Gizi Indonesia 2016;5(1):14-19. doi: 10.14710/jgi.5.1.14-19

27. Rayburn WF. Obstetrics and gynecology. Chalik (Alih bahasa). Jakarta: Widya Medika; 2001.

28. Zhao R, Xu L, Wu ML, Huang SH, Cao XJ. (2018). Maternal pre-pregnancy body mass index, gestational weight gain influence birth weight. Women Birth. 2018;31(1):e20-e25. doi: 10.1016/j.wombi.2017.06.003.

29. Haugen M, Brantsæter AL, Winkvist A, Lissner L, Alexander J, Meltzer HM, et al. Associations 
of pre-pregnancy body mass index and gestational weight gain with pregnancy outcome and postpartum weight retention: a prospective observational cohort study. BMC Pregnancy Childbirth. 2014;14:201. doi: 10.1186/1471-2393-14-201.

30. Abrams B, Altman SL, Pickett KE. Pregnancy weight gain: still controversial. Am J Clin Nutr. 2000;71(5 Suppl):1233S-41S. doi: 10.1093/ajen/71.5.1233s.

31. National Research Council and Institute of Medicine. Influence of pregnancy weight on maternal and child health. Workshop Report. Comite on The Impact of Pregnancy Weight on Maternal and Child Health. Washington DC: The National Academic Press; 2007.

32. Yongky, Hardinsyah, Gulardi, Marhamah. Status gizi awal kehamilan dan pertambahan berat badan ibu hamil kaitannya dengan BBLR. Jurnal Gizi dan Pangan 2009;4(1):8-12. doi: 10.25182/jgp.2009.4.1.8-12

33. Saputri R, Lestari LA, Susilo J. Pola konsumsi pangan dan tingkat ketahanan pangan rumah tangga di Kabupaten Kampar Provinsi Riau. Jurnal Gizi Klinik Indonesia 2016;12(3):123-130. doi: 10.22146/ijen.23110

34. Prihananto V, Sulaeman A, Riyadi H, Palupi NHS. Pengaruh pemberian makanan tambahan terhadap konsumsi energi dan protein ibu hamil. Jurnal Gizi dan Pangan 2007;2(1):16-21. doi: 10.25182/jgp.2007.2.1.16-21

35. Utami NW, Majid TH, Herawati DMD. Pemberian minuman formula kacang merah, kacang tanah, dan kacang kedelai terhadap satus gizi ibu hamil kurang energi kronis (KEK). Jurnal Gizi Klinik Indonesia 2017;14(1):1-9. doi: $10.22146 /$ ijen.22424 